\title{
Malformations produced by Varroa jacobsoni on Apis mellifera in the province of Buenos Aires, Argentina
}

\author{
J Marcangeli 1, L Monetti 1, N Fernandez 2 \\ 1 Universidad Nacional de Mar del Plata, facultad de Ciencias exactas y naturales, \\ laboratorio de Artropodos, Funes 3350, (7600) Mar del Plata, Buenos Aires; \\ 2 Consejo Nacional de Investigaciones Cientificas y Técnicas
}

(CONICET), Buenos Aires, Argentina

(Received 5 August 1991; accepted 26 May 1992)

\begin{abstract}
Summary - Morphological alterations caused by Varroa jacobsoni on recently emerged individuals of a local honey bee population were investigated. Contrary to previous reports, a high percentage of malformed bees resulted from a low number of mites per bee.
\end{abstract}

Varroa jacobsonil Apis mellifera / malformation

\section{INTRODUCTION}

The mite Varroa jacobsoni Oud used to be confined to southeastern Asia where it parasitized Apis cerana Fabr, but caused little damage due to its limited reproduction (Moritz and Hänel, 1984) and particular ethology (Peng et al, 1987).

However, Varroa jacobsoni develops on Apis mellifera $\mathrm{L}$ workers and drones (De Jong, 1984), and causes severe damage to the colony, ranging from malformation of bees (Samšinák and Haragsim, 1977 ) to the death of the colony (Grobov, 1977). De Jong et al (1982) studied the pathological effects of Varroa jacobsoni reflected in the weight of emerging Africanized bees and malformations on wings, legs and abdomen.
In this paper, malformations produced by the mite on the local "creole bee" ( $A \mathrm{~m}$ mellifera $\times$ A $m$ ligustica) were studied, relative to the parasitic intensity (number of mites per bee).

\section{MATERIAL AND METHODS}

Research took place during the autumn months (March and April) 1989. Work was done on brood frames from 5 hives which had not been chemically treated, within the districts of $\mathrm{Bal}$ carce and General Alvarado (Province of Buenos Aires, Argentina).

The frames were kept at a constant temperature $\left(35^{\circ} \mathrm{C}\right)$ up to the emergence of the bees. At the start of their eclosion, worker bees were removed with forceps and closely examined to determine the presence of mites. The brood 
cells were also examined to remove the remaining parasites. Unsealed cells were not considered.

Only adult female mites and deutonymph females were considered to determine parasitic intensity by brood cell, because the protonymph females and males are considerably smaller and, based on studies of weight loss after parasitism, do negligible damage (De Jong et al, 1982)

Bees were grouped according to the presence of malformations in their wings and abdomen. Wing malformations were grouped into 2 categories, 1 and 2 to increasing degree (figs 1 , 2). Pearson's correlation coefficient was applied to establish the correlation between the number of malformed bees and number of mites.

\section{RESULTS}

A total of 1045 bees were observed, among which 131 were parasitized. Twenty-nine percent of infested bees presented
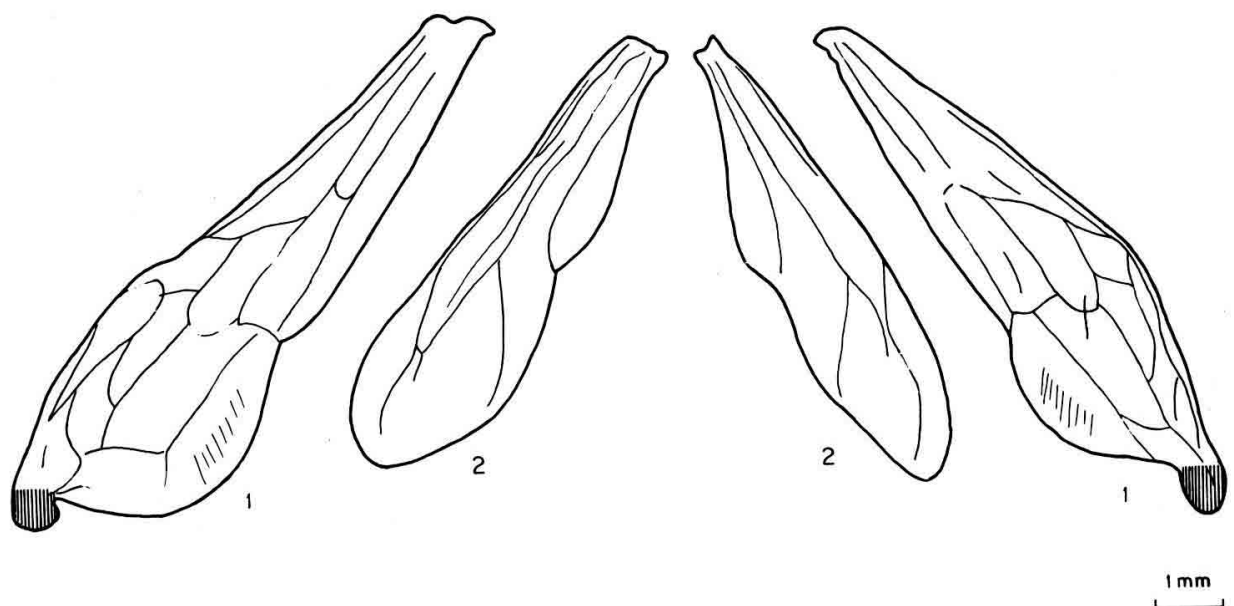

Fig 1. Wing malformation: type 1. 1: First pair of wings. 2: Second pair of wings.
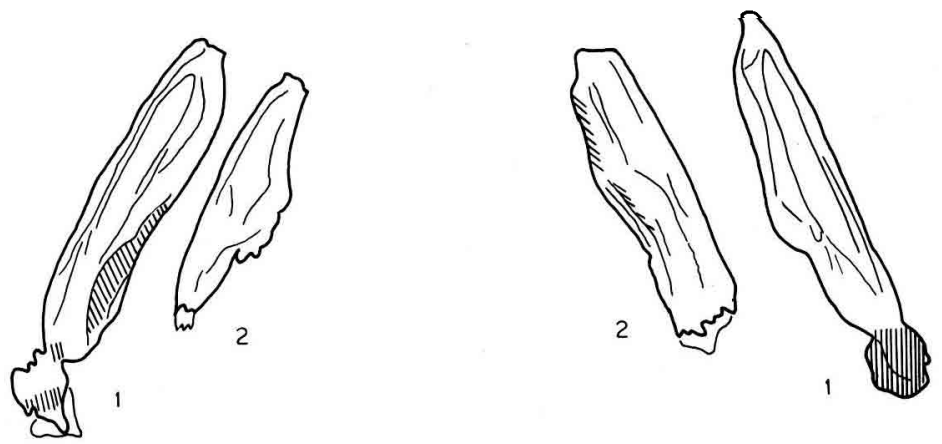

$1 \mathrm{~mm}$

Fig 2. Wing malformation: Type 2. 1: First pair of wings. 2: Second pair of wings. 
wing malformations. These presented parasitic intensities which varied between 1 and 7 , with a highly significant correlation between intensity and proportion of malformed bees $(r=0.94 ; P \leq 0.001)$ (table 1 ).

There were 36 bees with wing deformities, $50 \%$ of which presented a type 1 malformation and the other $50 \%$ type 2 . Those of type 1 had an average intensity of 2.55 mites and those of type 2 had an average intensity of 3.05 .

\section{DISCUSSION}

According to Samšinák and Haragsim (1977), symptoms of Varroa-infested bees consist of morphological alterations, the most characteristic being wing deformation. De Jong (1984) suggests that the damage to the wing is an external manifestation of loss of hemolymph, which results in insufficient hemolymph pressure to fully expand the wings following eclosion.

It is important to emphasize that malformations occurred at comparatively low intensities in our study. We found that malformations of the category 1 type occurred in honey bees with a parasitic intensity as

Table I. Number and proportion of malformed bees associated with different parasitic intensities.

\begin{tabular}{lcc} 
Parasitic No of & No of & Deformation \\
intensity bees & malformed bees & $(\%)$ \\
\hline
\end{tabular}

\begin{tabular}{rrrr}
\hline 0 & 914 & 0 & 0 \\
1 & 58 & 14 & 24 \\
2 & 32 & 5 & 16 \\
3 & 25 & 7 & 28 \\
4 & 8 & 4 & 50 \\
5 & 2 & 1 & 50 \\
6 & 4 & 3 & 75 \\
7 & 2 & 2 & 100 \\
\hline
\end{tabular}

low as 1 mite/bee, while those of category 2 were more likely with higher parasitic intensities. Both Africanized and European honey bees are known to exhibit major malformations with a parasitic intensity of 6 (De Jong et al, 1982; Ritter, 1986; Needham, 1988). Daly et al (1988) reported that parasitic intensities of 5 and 8 resulted in malformations that reduced front wing lengths $1.1 \%$ and $3.1 \%$ respectively.

In contrast to our observation that a high percentage $(29 \%)$ of infested bees have malformed wings, De Jong et al (1982) reported that Africanized bee exhibited malformations in only $6 \%$ of the individuals. These differences in damage between the honey bee races may be due to different post-capping periods. Given the interest in selected breeding of honey bees resistant or tolerant to Varroa, future research on the deleterious effects of the mite could benefit from comparative analysis of several races or strains of honey bee at a given location.

\section{ACKNOWLEDGMENTS}

This investigation was supported by an International Foundation for Science grant from Sweden, No B/ 1446-1 to N Fernandez. We wish to thank CEPA (Centro Experimental Para la Producción Apícola) for the use of their bees as part of this work. JM and LM are holder of an initiation grant at the Universidad Nacional de Mar del Plata, Argentina.

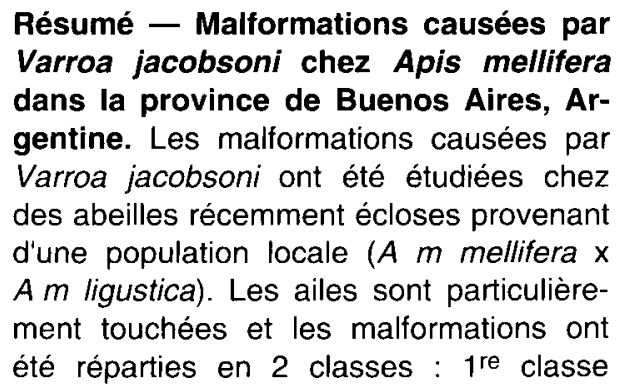


(fig 1, avec une infestation moyenne de 2,55 acariens/abeille) et $2^{e}$ classe (fig 2, avec une infestation moyenne de 3,05 acariens/abeille). Même dans le cas d'une infestation par un seul acarien, $24 \%$ des abeilles présentent des malformations. Plus l'infestation est forte, plus les malformations sont fréquentes. Avec une infestation de 6 acariens par cellule, $75 \%$ des abeilles écloses sont malformées (tableau I).

\section{Varroa jacobsoni / Apis mellifera / mal- formation}

Zusammenfassung - Mißbildungen bei Apis mellifera, verursacht durch Varroa jacobsoni in der Provinz Buenos Aires, Argentinien. Es wurden die Mißbildungen frischgeschlüpfer Bienen der lokalen Population als Folge des Befalls mit Varroa jacobsoni untersucht. Betroffen waren vor allem die Flügel, wobei zwei Grade der Mißbildung unterschieden wurden: Stufe 1 (Abb 1) bei einem mittleren Befall von 2,55 Milben) und Stufe 2 (Abb 2, bei einem mittleren Befall von 3,05 Milben). Schon bei einer Befall mit nur einem Milben waren $24 \%$ der Bienen mißgebildet. Je stärker der Befall, desto größer die Häufigkeit der Mißbildungen. Bei einem Befall mit 6 Milben pro Zelle waren $75 \%$ der geschlüpften Bienen mißgebildet (Tabelle II).

Varroa jacobsoni / Apis mellifera / Mißbildungen

\section{REFERENCES}

Daly $H$, de Jong D, Stone N (1988) Effect of parasitism by Varroa jacobsoni on morphometrics of Africanized worker honeybees. $J$ Apic Res 27 (2), 126-130

De Jong $D$ (1984) Current knowledge and open questions concerning reproduction in the honeybee mite Varroa jacobsoni. Adv Invertebr Reprod 3, 547-552

De Jong D, De Jong P, Gonçalves L (1982) Weight loss and other damage to developing worker honeybees from infestation with Varroa jacobsoni. J Apic Res 21 (3), 165-167

Grobov O (1977) La varroase des abeilles. In: La Varroase, Maladie de l'Abeille Mellifère. Apimondia, Bucharest, 52-79

Moritz R, Hänel H (1984) Restricted development of the parasitic mite (Varroa jacobsoni Oud) in the Cape honeybee Apis mellifera capensis. $Z$ Angew Entomol 97, 91-95

Needham G (1988) Status report on Varroa jacobsoni. Am Bee J 128 (2), 106-110

Peng $Y$, Fang $Y, Y u S$, Ge $L$ (1987) The resistance mechanism of the Asian honeybee, Apis cerana Fabr to an ectoparasitic mite Varroa jacobsoni Oudemans. I Invertebr Pathol 49, 54-60

Ritter W (1986) La varroatosis de la abeja, Apis mellifera y su tratamiento con Perizin. Not Méd Vet 1, 3-16

Samsinak K, Haragsim O (1977) L'acarien Varroa jacobsoni pénètre en Europe. In: La Varroase, Maladie de l'Abeille Mellifère. Apimondia, Bucharest, 29-31 